\title{
GENERATION Y: MODERATING EFFECT OF MOTIVATION ON THE RELATIONSHIP BETWEEN REWARDS AND LOYALTY
}

\author{
Shahrul Nizam Salahudin* \\ Universiti Islam Sultan Sharif Ali, Gadong BE 1310, Brunei \\ Mohd Nur Ruzainy Alwi \\ Universiti Tenaga Nasional, 26700 Muadzam Shah, Pahang, Malaysiaheng-Kuang \\ Siti Sarah Baharuddin \\ Universiti Tenaga Nasional, 26700 Muadzam Shah, Pahang, Malaysiaheng-Kuang \\ Nurul Nabilah Ali \\ Universiti Islam Sultan Sharif Ali, Gadong BE 1310, Brunei
}

\begin{abstract}
Employee loyalty among generation $\mathrm{Y}$ workers has been focus in many studies as many employees in this generation job hop from one organization to another. One of the main reason found is the opportunity of better compensation and rewards in other organization. Thus, the focus of this study is to investigate the relationship between rewards and loyalty among generation Y. Besides that, previous research stated that through rewards, employee gain motivation to stay committed to the organization. Hence, motivation is studied as the moderator of the relationship between rewards and loyalty. The self-administered questionnaires were distributed to generation $\mathrm{Y}$ in the capital of Malaysia regardless of their sectors and level of management. Structural models were constructed for hypothesis testing and the result founds that rewards have a significant relationship with loyalty. This study also found that motivations do not strengthening or weakening the effects of rewards on loyalty.
\end{abstract}

Keywords: Rewards, Loyalty, Employee Motivation, Generation $Y$ 


\section{INTRODUCTION}

Loyalty issue among generation $\mathrm{Y}$ has arises in much research as a problem of this generation and imposed risk for many organizations especially at the time of high competitiveness. Talent attraction and retention have become essential strategy in big organization that realizes the cost of high turnover and disloyalty. Besides that, employee loyalty related to desirable consequences such as employees' high commitment ${ }^{1}$, profitability, ${ }^{2}$ improves organizational performance ${ }^{3}$ and reduced attention to quit ${ }^{4}$. Hence, organizations need to create and implement policies as well as strategies with employee's loyalty as the main focus of the organization 5 .

Besides that, disloyalty may cause turnover and incurred various costs on the organization. The cost of high turnover often greater than the cost of providing good rewards system as it does not only cost organization financially but also on organization performance 6 . It also affected the motivation of remaining employees especially on knowledge transfer and morale. ${ }^{7}$ On the other hand, loyalty is not only about staying with the organization but also the On the other hand, loyalty is not only about staying with the organization but also the commitment employees have when they are in the organization. Employee loyalty depicts the ability to direct employee behavior towards the realization of organizational goal ${ }^{8,9}$.

Thus, disloyalty does not only cause turnover but also behavioral problem. In some cases, employee stays due to no other employment opportunity or high cost of switching so their commitment only at the par of getting a salary every month, without much motivation of doing their work. It causes a decline in job performance as they neglecting their responsibility in helping organization to achieve its goal ${ }^{10}$.

Furthermore, based on the study conducted in 18 countries, involving 11000 generation $\mathrm{Y}$ workers, generation $\mathrm{Y}$ is more likely to stay with the company if they have a pay increase or bonus, a new challenge or promotion and being recognized by their employer and colleagues ${ }^{11}$. This report shows that rewards and motivation play an important role in ensuring loyalty among generation $\mathrm{Y}$ and research on both subjects essential in understanding how it works. The loyalties that are based on the financial exchange between employees and their organization make them easily change the organization at the sight of better rewards ${ }^{6}$. Besides that, generation $\mathrm{Y}$ workers continuously look for feedback from their managers and colleague in which they expect continuous direction in their performance as part of motivation ${ }^{12}$. Therefore, this study aims to investigate the relationship between rewards and loyalty among generation $Y$ and the interaction of motivation as the moderator.

\section{2. $\quad$ LITERATURE REVIEW}

Rewards, motivations and employee loyalty are very crucial issues in any organizations. It is through good rewards system together with the impact of motivation that organization can achieve organizational goals and objective. It is hope through these two factors too can it enforces employees' loyalty towards the organization. By definition, employee loyalty is the ability of an employee to stay and be faithful to the organization for a certain extent 13,14 . However, a more comprehensive definition of job loyalty, employee's commitment towards the organization also included. It is stated that employee loyalty is the willingness of employees to expense and invest in while serving the organization in order to strengthen its development ${ }^{2}$. This willingness to sacrifice is due to the strong feeling of responsibility employee has towards their organization ${ }^{15}$. 
These responsibilities originally started when employee start entering the organization. It is through psychological contract between employee and employers that the responsibility later converted to reward as the compensation of employees work. Reward is the benefits that the employees' gain from serving the organization and fulfilling their responsibility ${ }^{16}$. It can be broadly categorized into intrinsic (nonmonetary) and extrinsic (monetary). Intrinsic reward is the result of completing the task which psychologically gains by the employees such as satisfaction, recognition, praise and others ${ }^{17}$. Meanwhile, extrinsic reward is the monetary benefits employee received, compensated for their efforts and times working for the organization ${ }^{18}$.

In the case of good performance, organization usually pays extra extrinsic rewards as a mean of recognition and appreciation. The extrinsic rewards are expected to fulfil physiological needs while intrinsic rewards fulfil the psychological need ${ }^{19}$. It is part of psychological contract employees expected from their employment ${ }^{20}$. Based on this understanding, rewards system is one of the important factors that mediate the employer and employee relationship. Once this psychological contract is broken, employee work will start to diminish, causing deviance behavior or worse, disloyalty among employees $^{21-22}$. Thus, it is expected that rewards has an influence in employee loyalty.

\section{H1: There is a significant relationship between rewards and employee loyalty among Generation Y.}

In addition to the relationship between rewards and employee loyalty, potential moderator effect of motivation may also need to be studied. Based on the previous study, rewards are able to improve employee performance through motivation in which motivation is a drive force that shape employee act and behavior in achieving both organizational and individual purposes ${ }^{23}$. These forces originate within and beyond an individual and able to determine the form, direction, intensity and duration of work ${ }^{24}$. It is from the process of motivation itself that require the process of arousing, directing and maintaining behavior towards a goal25. Breaking the definition into components, motivation started with a drive or energy to act (arousal) which directed certain set of behaviours (direction) and persistency in making efforts (maintaining) until the goal is achieved $^{26}$.

The motivated behavior imparts commitment until completion of goal thus directly implies commitment towards the organization. Loyalty in the form of commitment drives the employee to act and even sacrifice their self-interest for the sake of their organization ${ }^{27}$. The willingness to put aside the personal needs for the sake of the organization is the indicators of loyalty which may be based on the perceived obligation and reciprocity in the employment relationship 28 . Hence, organizational strategies and policies must include employee motivation as part of the focus. Reward is one of the factor that motivate employees to perform as expected ${ }^{29}$. A well-designed rewards system is necessary to motivate employees to put their best effort and encouraging sense of loyalty towards the organization ${ }^{2}$. On the other hand, poor rewards system may cause dissatisfaction among employees then diminish their motivation to work and finally resulted in leaving the organization ${ }^{30}$. 
As employee loyalty is a complex multi-faceted construct, it can be view from various perspectives, either as a set of behaviour ${ }^{31-32}$, attitude ${ }^{33}$ or psychological traits ${ }^{34-35}$. The behavior and attitude shown from loyalty reflected in the employee performance and values of loyalty make them stay with the company as long as they feel that their loyalty worthy 33,36 . Thus, rewards system need to be effective in stimulating motivation from employee to encourage behavior directed in achieving organizational goals. Both intrinsic and extrinsic rewards must motivate employees' behavior internally and externally towards the direction of organization. For instance, intrinsic rewards employee need from job satisfaction is part of the internal motivation required to maintain their efforts in achieving goals ${ }^{37}$. Meanwhile, the extrinsic rewards strive to boost extrinsic motivation through external incentive such as bonus and other monetary rewards ${ }^{38}$. Together, motivation may be able to strengthen the impact of rewards on loyalty. Therefore, it is expected that the effects of reward on loyalty are likely to be greater with high motivation from employees:

\section{H2: Motivation strengthens the relationship between rewards and employee loyalty among Generation Y.}

\section{METHODS}

The study use self-administered questionnaires which distributed to various generation Y employees in Kuala Lumpur area and its vicinity. Generation Y definition used in this study is the employees aged 17 to 37 years old 39 . Out of the total questionnaire 300 questionnaires distributed, only 202 were used for this study with response rate of 67.3 per cents. Table 1 shows the summarized demographic profile of the respondents. The demographic profile of the respondents were analyzed using IBM SPSS while the structural equation modelling were constructed using IBM AMOS.

Table 1: Demographic profile of respondents

\begin{tabular}{l|l|l}
\hline $\begin{array}{l}\text { Demographic } \\
\text { Attributes }\end{array}$ & Frequency (\%) & 42.6 \\
Gender & Male & 57.4 \\
\hline \multirow{4}{*}{ Age } & Female & 7.9 \\
& $16-20$ & 50.0 \\
& $21-25$ & 22.8 \\
\hline \multirow{5}{*}{ Sector } & $26-30$ & 19.3 \\
\hline & $31-36$ & 3.0 \\
& Insurance & 2.0 \\
& Retail & 13.9 \\
& Financial Institution & 35.1 \\
& Hospital & 5.4
\end{tabular}

Submit Date: 10.07.2018, Acceptance Date: 22.08.2018, DOI NO: 10.7456/1080SSE/154

Research Article - This article was checked by Turnitin

Copyright (C) The Turkish Online Journal of Design, Art and Communication 


\begin{tabular}{l|l|l} 
& IT & 0.5 \\
Employment & Others & 40.1 \\
\hline Level & Non-executive & 65.3 \\
& Executive & 23.3 \\
& Senior Executive & 6.4 \\
\hline \multirow{5}{*}{ Qualification } & Manager & 5.0 \\
\hline & PMR & 1.5 \\
& SPM & 22.3 \\
& STPM & 7.9 \\
& Certificate & 4.5 \\
& Diploma & 27.2 \\
\hline
\end{tabular}

\section{RESULTS}

The analysis involved Structural Equation Modelling (SEM) which tested on two main stages; measurement and structural model. Confirmatory factor analysis (CFA) was used in analysing measurement model. The model fit assessed using category of model fit and after deleting items with low factor loading as well as setting the pair of redundant items as free parameter estimate, the measurement model found to be in a good fit for further analysis $(\mathrm{c} 2 / \mathrm{df}=2.297 ; \mathrm{CFI}=0.902 \text {; RMSEA }=0.080)^{40}$. The factor loading for of the manifest indicators onto their respective latent variables were all statistically significant, ranging from 0.60 to 0.90 .

The reliability and validity of the model is shown in table 2. Reliability was measured using internal consistency reliability through Cronbach's alpha coefficient and composite reliability ${ }^{41}$. The result showed that the model has a good reliability as it meets a satisfactory level of composite reliability and Cronbach's alpha with value more than $0.70^{40}$. Meanwhile, validity is confirmed through convergent validity and discriminant validity. Convergent validity was assessed using average variance and the result shows that it is acceptable. In term of discriminant validity, it is met when the variance of its own measures is greater than value of variance shared with other constructs ${ }^{42}$. Based on table 2, the discriminant validity is achieved with the entire square roots of the AVEs are greater than all inter-construct reliability ${ }^{40}$.

In this study, 2 hypotheses were examined and the result of hypotheses testing showed in table 3 and fig. 1 (model 1) and fig. 2 (model 2). Table 3 shows the path coefficient between variables with (model 1) and without moderator (model 2). The result of model 1 shows that rewards have a significant relationship with employee loyalty. Moreover, the value of R2 shows that the constructs explain the loyalty at 68.0 $\%$. Thus, hypothesis 1 is supported.

Table 2: Reliability and Validity Results

\begin{tabular}{|l|l|l|l|}
\hline & Cronbach' & & Discriminant Validity \\
\hline
\end{tabular}

Submit Date: 10.07.2018, Acceptance Date: 22.08.2018, DOI NO: 10.7456/1080SSE/154

Research Article - This article was checked by Turnitin

Copyright (C) The Turkish Online Journal of Design, Art and Communication 
The Turkish Online Journal of Design, Art and Communication - TOJDAC

ISSN: 2146-5193, September 2018 Special Edition, p.1130-

\begin{tabular}{|l|l|l|l|l|l|l} 
& S alpna & LN & RVL & 1 & 2 & 3 \\
\hline 1. Rewards & 0.906 & 0.921 & 0.497 & $\mathbf{0 . 7 0 5}$ & & \\
\hline 2. Motivation & 0.889 & 0.913 & 0.6 & 0.654 & $\mathbf{0 . 7 7 5}$ & \\
\hline 3. Loyalty & 0.889 & 0.909 & 0.506 & 0.625 & 0.714 & $\mathbf{0 . 7 1 1}$ \\
\hline
\end{tabular}

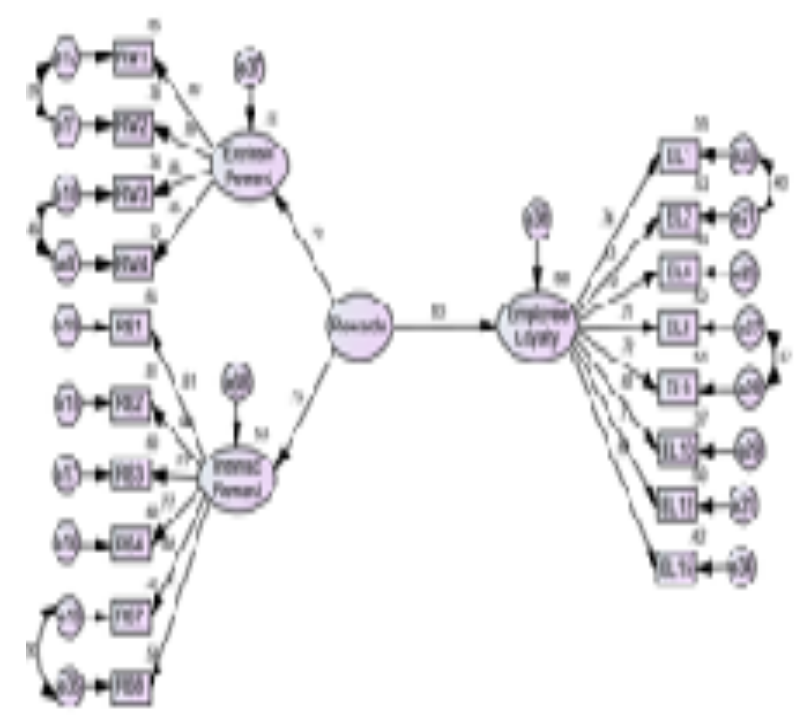

Fig. 1: Structural model 1 without moderator.

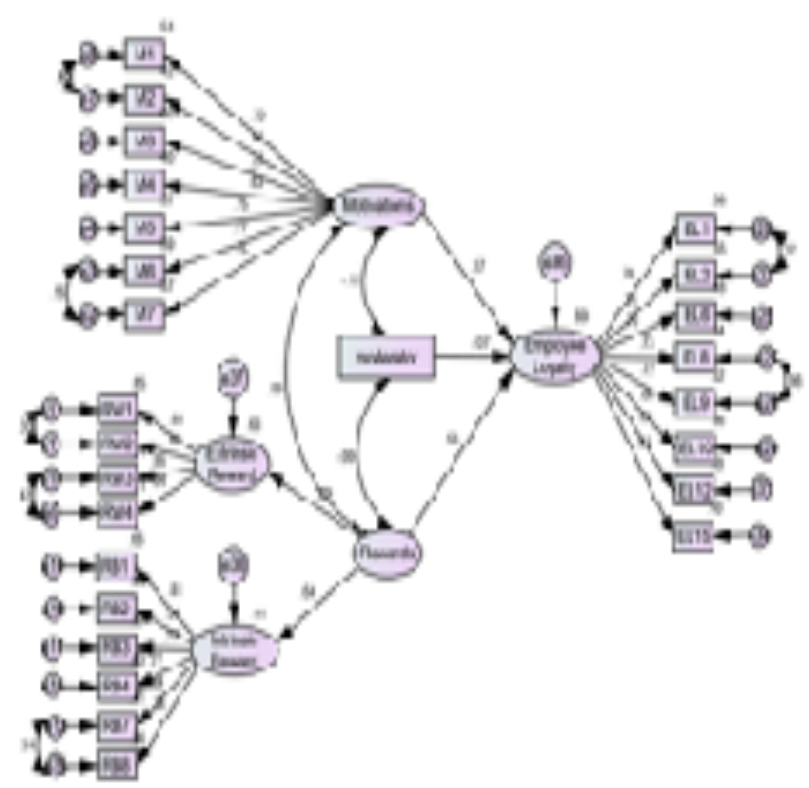

Fig. 2: Structural model 1.

Submit Date: 10.07.2018, Acceptance Date: 22.08.2018, DOI NO: 10.7456/1080SSE/154

Research Article - This article was checked by Turnitin

Copyright (C) The Turkish Online Journal of Design, Art and Communication 
After analyzing for direct relationship, interacting effect of motivation on loyalty was investigated for hypothesis 2 . Fig 2 shows the model 2 after adding a moderator. However, as shown in table 3 , the moderator has no significant effect on the relationship with $p$-value is not significantly different from zero $(p=0.202)$. Thus hypothesis 2 is not accepted and motivation is not a moderator variable even though there is a change in the variance of loyalty from 0.68 to 0.69 .

Table 3: Statistical result of hypothesis testing

\begin{tabular}{|c|c|c|c|c|}
\hline \multicolumn{2}{|c|}{$\begin{array}{l}\mathrm{H} \text { y } \mathrm{p} \text { o } \mathrm{t} \text { h e } \mathrm{t} \text { i c a } 1 \\
\text { relationship }\end{array}$} & \multirow{2}{*}{$\begin{array}{l}\mathrm{P} \text { a } \mathrm{t} h \\
\text { Coeffic } \\
\text { ient } \\
0.832\end{array}$} & \multirow{2}{*}{$\begin{array}{l}\mathrm{P} \\
0.000\end{array}$} & \multirow{2}{*}{$\begin{array}{l}\mathrm{R}^{2} \\
\text { value } \\
0.68\end{array}$} \\
\hline $\begin{array}{l}\mathrm{H} \\
1\end{array}$ & Rewards -> Loyalty & & & \\
\hline \multicolumn{5}{|c|}{ After adding a moderator } \\
\hline & Reward -> Loyalty & 0.56 & 0.001 & \multirow{3}{*}{0.69} \\
\hline & $\begin{array}{l}\text { Motivation -> } \\
\text { Loyalty }\end{array}$ & 0.27 & 0.000 & \\
\hline $\begin{array}{l}\mathrm{H} \\
2\end{array}$ & $\begin{array}{l}\text { ( R e w a rd } \\
\text { Motivation }) \\
\text { Loyalty }\end{array}$ & -0.07 & 0.151 & \\
\hline
\end{tabular}

\section{CONCLUSION}

This study aimed to investigate the relationship between rewards and loyalty among generation $\mathrm{Y}$ with motivation as moderator. As the data involved various sectors, the focus on the study only on generation $Y$ regardless of their type of employment and the sector they work in. Based on the results, rewards have direct effect on the loyalty and it is aligned with other research. The results of second hypothesis found that motivation does not moderate the relationship between rewards and employees among generation Y. It shows that motivation in this study is not sufficient to increase the impact of rewards on employee loyalty.

Rewards do not necessarily affected motivation as some employees seek more responsibility in their job and get motivation more based on the work aspects rather than external drive ${ }^{17}$. For instance, freedom in work, space for creativity and task significance increase meaningfulness of their jobs and result in higher internal work motivation thus better work commitment ${ }^{43}$. Besides that, generation Y worker also have potential fluidity in career especially with advancement of technology and globalization causing them to change organization based on their own value rather than organization aspects $^{6}$. They also have lowered level of organizational commitment and more concerned with high monetary rewards ${ }^{44-45}$. 
In conclusion, further research should investigate other factors that may moderate the effect between rewards and loyalty. The finding implied that great rewards system is essential to ensure employee loyalty among generation Y. However, the results must be used in caution as it does not eliminate the effects of other aspects of job characteristics or factors that may have influence on loyalty either in interaction of rewards or not. In practical, employers can do exit interview as a mean to gather data in relation to employee turnover and loyalty ${ }^{46}$. Meanwhile, in research level, future study can include a larger sample and across range of different jobs requiring a wide range of skills that may increase statistical power.

\section{REFERENCES}

1. $\quad$ M. Dzirin and A. Schneider, Employ. Relat. Today, 43 (2004)

2. A.M. Albalooshi, A. Ali, and A.A. Al-Ansi, Int. Bus. Manag. 3, 11 (2017)

3. S. Brown, J.M. McHardy and K. Taylor, J. Eco. Manag. Strategy, 20, 3 (2011)

4. Z. Ton and R.S. Huckman, Org. Sci. 19, 1 (2008)

5. O.A. Shvetsova, IEEE Conference on quality management, transport and information security, information technologies, IT and MQ and IS, (2016)

6. S.N. Salahudin, M.N.R. Alwi, S.S. Baharuddin and N.I.A. Samad, Euro Proceedings Soc. Behav. Sci. 17, (2016)

7. $\quad$ Asian Institutes of Finance, Asian Link 15, (2014)

8. A. Luchak, Brit. J. Ind. Relat. (2003)

9. R.W.Y. Yee, A.C.L. Yeung and T.C.E. Cheng. Int. J. Prod. Eco. 124, 1 (2010)

10. M. AbdulRahman, Int Bus Manag, (2017)

11. Manpower Group, Millenial Careers: 2020 Vision, (2017)

12. A. Blain, J. Qual. Assur. Inst. 22, 2 (2008)

13. R. Silvestro, Int. J. Oper. Prod. Manag. 22, 1 (2002)

14. L.-M. Tseng and J.-Y. Wu, Leadership Org. Dev. J. 38, 5 (2017)

15. J.B. Avey, T.S. Wernsing and M.E. Palanski, J. Bus. Ethics 107, 1 (2012)

16. M.O. Agwu, J. Edu. Soc. Behav. Sci. 3, 1 (2013)

17. M. Harunavamwe and H. Kanengoni, Afr. J. Bus. Manag. 7, 38 (2013)

18. N. Khan, H. Waqas, R. Muneer, Euro. J. Bus. Manag. 8, 25, (2016)

19. N. Chijioke and F. Chinedu, Euro. J. Bus. Manag. 7, 4, (2015)

20. S.S., Baharuddin, M.N.R., Alwi, M.A.A.A., Hassan, N.E., Omar, \& N.A. Ismail, Int. J. Bus. Manag. (2017)

21. S., Bashir, and M. Nasir, Int. J. Hosp. Manag. 34, 1, (2013)

22. S., Umar and K.J. Ringim, Management and International Conference, (2015)

23. M.A.D. Ikhram and A. Sudjatno, J. App. Manag. 15, 1, (2017)

24. G.P Latham and C.C. Pinder, Annual Rev. Psycho. 56, 1, (2005)

25. T.R. Mitchell, Academy of Management Review, 7, 1 (1982)

26. M.J. Karimi, University of Nairobi (2013)

27. J.M. Elegido, J. Bus. Ethics (2013)

28. D. Shekhar and D. Kumar, J. Manag. Research 12, 2 (2012)

29. D.E. Guest and N. Conway, Human Res. Manag. J. 12, 2 (2002)

30. M.M. Shafiq and M.A. Naseem, SSRN Electronic J. (2011)

31. P.P. Carson, K.D. Carson, B. Birkenmeier and A.G. Toma, Public Personnel Manag. 35, 2 (2006) 
32. C.E. Rusbult, D. Farrell, G. Rogers and A.G. Mainous III, Academy Manag. J. 31, 3 (1988).

33. D.W. Hart and J.A. Thompson, Bus. Ethics Quarterly 17, 2 (2007)

34. J. Boxill, Sports Ethics (2003)

35. D. Mele, Bus. Ethics Quarterly 11, 1 (2001)

36. K. Seetman, MIT Sloan Manag. Rev. 16 (2001)

37. C. Ajila and A. Abiola, J. Soc. Sci. 8, 1 (2004)

38. E.L. Deci and R.M. Ryan, Psycho. Inquiry 11, 4 (2000)

39. S.P Robbins, T.A. Judge and N. Vohra, Organizational Behaviour, Pearson, NJ (2011)

40. J.F., Hair, W.C., Black, B. J., Babin and R.E. Anderson, Multivariate Data Analysis: a global perspectives, Pearson Prentice Hall, NJ (2010)

41. W. Chin, Handbook of Partial Least Squares, Springer, Heidelberg (2010)

42. $\quad$ C., Fornell and D.F. Larcker, J. Marketing Research 18, 3 (1981)

43. R., Daft and D. Marcic, Management: The New Workplace, Mason Ohio Thompson, South Western (2007)

44. K. P. De Meuse and K. J. Mlodzik, People and Strategy 33, 2 (2010)

45. J.M. Twenge, and S.M. Campbell, IEEE Engineering Manag. Rev. 39, 2 (2011)

46. E.A. Hoffmann, Social Forces 84, 4 (2006) 